\title{
Basin-wide water accounting based on remote sensing data: an application for the Indus Basin
}

\author{
P. Karimi ${ }^{1,2}$, W. G. M. Bastiaanssen ${ }^{2,3}$, D. Molden ${ }^{4}$, and M. J. M. Cheema ${ }^{5}$ \\ ${ }^{1}$ International Water Management Institute, Battaramulla, Sri Lanka \\ ${ }^{2}$ Faculty of Civil Engineering and Geosciences, Water Management Department, \\ Delft University of Technology, Delft, the Netherlands \\ 3 eLEAF Competence Centre, Wageningen, the Netherlands \\ ${ }^{4}$ International Centre for Integrated Mountain Development, Kathmandu, Nepal \\ ${ }^{5}$ Department of Irrigation and Drainage, University of Agriculture, Faisalabad, Pakistan \\ Correspondence to: P. Karimi (p.karimi@cgiar.org, p.karimi@tudelft.nl)
}

Received: 25 October 2012 - Published in Hydrol. Earth Syst. Sci. Discuss.: 13 November 2012

Revised: 7 June 2013 - Accepted: 7 June 2013 - Published: 4 July 2013

\begin{abstract}
The paper demonstrates the application of a new water accounting plus (WA+) framework to produce information on depletion of water resources, storage change, and land and water productivity in the Indus basin. It shows how satellite-derived estimates of land use, rainfall, evaporation $(E)$, transpiration $(T)$, interception $(I)$ and biomass production can be used in addition to measured basin outflow, for water accounting with WA+. It is demonstrated how the accounting results can be interpreted to identify existing issues and examine solutions for the future. The results for one selected year (2007) showed that total annual water depletion in the basin $\left(501 \mathrm{~km}^{3}\right)$ plus outflows $\left(21 \mathrm{~km}^{3}\right)$ exceeded total precipitation $\left(482 \mathrm{~km}^{3}\right)$. The water storage systems that were effected are groundwater storage $\left(30 \mathrm{~km}^{3}\right)$, surface water storage $\left(9 \mathrm{~km}^{3}\right)$, and glaciers and snow storage $\left(2 \mathrm{~km}^{3}\right)$. Evapotranspiration of rainfall or "landscape ET" was $344 \mathrm{~km}^{3}$ (69\% of total depletion). "Incremental ET" due to utilized flow was $157 \mathrm{~km}^{3}$ ( $31 \%$ of total depletion). Agriculture depleted $297 \mathrm{~km}^{3}$, or $59 \%$ of the total depletion, of which $85 \%\left(254 \mathrm{~km}^{3}\right)$ was through irrigated agriculture and the remaining $15 \%\left(44 \mathrm{~km}^{3}\right)$ through rainfed systems. Due to excessive soil evaporation in agricultural areas, half of all water depletion in the basin was non-beneficial. Based on the results of this accounting exercise loss of storage, low beneficial depletion, and low land and water productivity were identified as the main water resources management issues. Future scenarios to address these issues were chosen and their impacts on the Indus Basin water accounts were tested using the new WA+ framework.
\end{abstract}

\section{Introduction}

The aim of water accounting is to track inflows and outflows, assets, liabilities, stocks and reserves for a particular area over a period of time. Outcomes are essential for both current and future water management decisions. Water accounting principles are described in detail by for instance Godfrey and Chalmers (2012). Availability of data on water flows and consumption is a major constraint for reliable accounting in river basins worldwide. For this reason, data intensive water accounting frameworks such as the United Nations System for Environmental and Economic Accounting for Water (SEEAW) (UN, 2007), which tracks water withdrawal by different sectors, are not commonly implemented (Karimi et al., 2012).

Water accounting plus (WA+) (Karimi et al., 2013) presents water accounts of river basins using four sheets including (i) a resource base sheet, (ii) an evapotranspiration sheet, (iii) a productivity sheet, and (iv) a withdrawal sheet. The resource base sheet gives information on water volumes. Water supply and water depletion processes are presented. The evapotranspiration sheet shows how beneficial the water depletion is. The productivity sheet shows links between water depletion and biomass production, carbon sequestration, crop production and water productivity. The withdrawal sheet provides information on water withdrawals and reuse. The latter sheet is relevant for managing the water cycle and meeting water allocation agreements. Every sheet has a set of indicators that summarizes the overall water resources 
situation. WA+ explicitly recognizes the influence of land use on the water cycle. To provide the link between water balance, land use and water use, and management options to modify it, WA+ groups land use classes with common management characteristics into the following: conserved land use (CLU), utilized land use (ULU), modified land use (MLU), and managed water use (MWU). CLU includes National Parks and other protected areas, ULU is land use with intensive ecosystem services, MLU is land with human influences such as the cultivation of rainfed crops, plantations and soil treatment. Withdrawals in the MWU class is by means of man-made infrastructure (diversion dams, canals, ditches, pumping stations, gates, weirs, pipes, etc).

The large Indus basin, with many challenging water problems (Eastham et al., 2010; Qureshi, 2011), was selected to illustrate the WA+ applications. The fundamental data on water resources and distributed flows in basins such as the Indus basin are limited and the majority of the basin is ungauged. The size of the basin, budget constraints and its transboundary nature hamper the establishment of a comprehensive measurement network. For example, less than four rain gauge stations are available per $10000 \mathrm{~km}^{2}$. The situation is worse for in situ soil moisture and evapotranspiration measurements. Information on land use and crop rotation systems is similarly scant. Available databases are old, coarse and do not cover the entire basin. Satellite-derived data can improve such inadequacies. The application of WA+ in the basin is described using an "accounting period" of one year. The year 2007 was selected due to availability of remote sensing (RS) data (Cheema, 2012). The objective of this paper is thus to demonstrate how WA+ can contribute to describing the water resources conditions of a basin and how it can be used to identify and assess the impact of potential solutions to the water problems. It is important to note that, since this study is only based on one year accounting, results should be treated with caution and it would be premature to use them to formulate recommendations to the agencies of the Indus Basin.

\section{The Indus basin}

The Indus basin (Fig. 1) occupies an area of $1160000 \mathrm{~km}^{2}$ in total. It is shared by Pakistan, India, China, and Afghanistan, each respectively occupying $53,33,8$, and $6 \%$ of the basin area. With a population of about 250 million, the basin is among three major highly populated river basins in South Asia alongside the Ganges and Brahmaputra basins. The climate is primarily arid and semi-arid. Hence rainfed agriculture is insufficient to feed the growing population, and food production relies on irrigation. The basin is home to one of the biggest and most intensive irrigation schemes in the world: the Indus Basin irrigation system (IBIS) with an estimated command area of approximately $16000000 \mathrm{ha}$. Including the Indian part of the Indus basin, the total irrigated

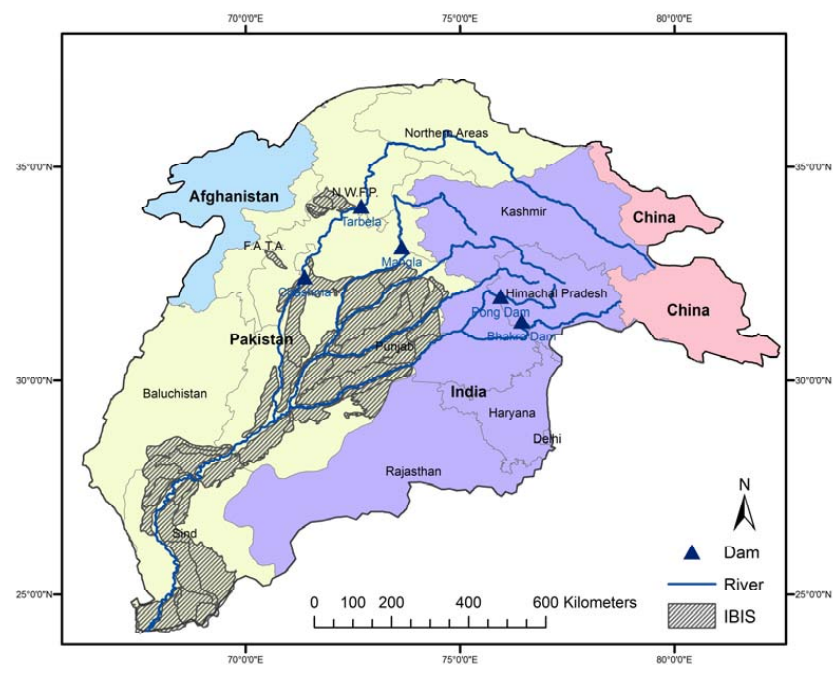

Fig. 1. The Indus basin.

area is $26000000 \mathrm{ha}$, comprising $22 \%$ of the total area of the basin.

The basin hydrology is complex due to the high variability in climatic and geomorphic features. The basin population is highly dependent on extensive irrigation agriculture, which long ago exceeded the threshold for sustainable water consumption (Habib, 2000). The irrigation practices run on the expense of rapidly decreasing groundwater resources. Siebert et al. (2010) and Wada et al. (2010) indicated independently that the Indus basin has one of the most overexploited groundwater systems worldwide. Besides the unsustainable use of groundwater, the other major challenges that the basin faces include the increasing gap between supply and demand, water logging in poorly drained areas, climate change impacts, environmental degradation, soil salinization, and above all, political disagreements among riparian countries (Qureshi, 2011).

\section{Data}

\subsection{Land use and land cover}

Land use and land cover (LULC) affect the water balance, as well as the benefits and services for society and for the environment. Spatially distributed information on LULC is thus the key information required by WA + . Whereas LU relates to a specific use of land (e.g. production pasture), LC describes the physical state of that particular land surface (e.g. grass). There are a number of global and regional land cover databases based on remotely sensed data using different algorithms (e.g. Bartholomé and Belward, 2005; Bontemps et al., 2010; Friedl et al., 2010; Thenkabail et al., 2005). These products mainly provide LC data and information related to LU is limited. 
An existing LULC map of the Indus, developed by Cheema and Bastiaanssen (2010), was used for this study. It is based on the seasonal phenological variations of 27 classes from temporal profiles of NDVI from SPOT Vegetation. Different crop classes were identified and verified through ground truth campaigns. The LULC classes have been re-grouped into four major clusters that differ in terms of water management: conserved land use (CLU), utilized land use (ULU), managed land use (MLU) and managed water use (MWU). The area under CLU is $83081 \mathrm{~km}^{2}$, ULU is $612184 \mathrm{~km}^{2}$, MLU is $174100 \mathrm{~km}^{2}$ and MWU is $278279 \mathrm{~km}^{2}$.

To define protected areas, the International Union for Conservation of Nature (IUCN) and United Nation Environment Programme (UNEP) database for protected areas was used. These bodies publish digital boundaries of conserved land use classes (e.g. http://www.protectedplanet.net/).

\subsection{Precipitation}

WA + uses gross precipitation as the primary input. Precipitation products such as the Tropical Rainfall Measurement Mission (TRMM), the Climate Prediction Center Morphing Technique (CMORPH) (Joyce et al., 2004), and the Precipitation Estimation from Remotely Sensed Information using Artificial Neural Networks (PERSIANN) (Sorooshian et al., 2000), provide free global precipitation data with different spatial and temporal resolutions.

Rainfall data from the calibrated TRMM map was used for this accounting procedure. Cheema and Bastiaanssen (2012) calibrated TRMM rainfall for the Indus basin with two methods including (a) a regression analysis against rain gauges and (b) a geographical differential analysis (GDA). Using the Nash-Sutcliffe efficiency (NSE) and standard error of estimates (SEE) they concluded that calibration with the GDA method resulted in a closer correlation with rain gauge data than a simple regression equation. Both calibrations in general showed a reasonable accuracy however (NSE $>0.8$ ). The quality of the GDA method is highly dependent on the distribution of rain gauges in the network. In the Indus basin the majority of stations are located in the low altitude plains, whereas most of the precipitation occurs in the mountainous ungauged part of the basin. The GDA method is thus likely to underestimate rainfall in the northern mountains and highlands. For these reasons, and to overcome the issue of underestimation of the rainfall by the GDA method, a new map was produced which combines the result of the two calibrations. The resulting map is shown in Fig. 2a. The annual rainfall in the basin (using the combined method) was $415 \mathrm{~mm} \mathrm{yr}^{-1}$ (i.e. a volume of $482 \mathrm{~km}^{3}$ ) in 2007. Laghari et al. (2012) reported an average long-term annual precipitation in the Indus basin of 446 to $497 \mathrm{~km}^{3}$ based on two datasets (GWSP, 2008; Hijmans et al., 2005) and figures provided by various authors (Immerzeel et al., 2010; Karim and Veizer, 2002; Mitchell and Jones, 2005). The range compares well with our estimate, especially seeing that 2007 was a wet year (PBS, 2008).

\subsection{Evapotranspiration and biomass production}

Various methods and algorithms to estimate actual evapotranspiration (ET) through satellite measurements have been developed over the past decades. Methods such as SEBAL (Bastiaanssen et al., 1998), SEBS (Su, 2002), TSEB (Norman et al., 2000), METRIC (Allen et al., 2007), Alexi (Anderson et al., 2007) and ETWatch (Wu et al., 2012), amongst others are used widely to estimate ET and are increasingly accepted (e.g. Kalma et al., 2008; Verstraeten et al., 2005). Products such as MOD 16 (http://modis.gsfc.nasa.gov) offer daily ET data at $1 \mathrm{~km}^{2}$ resolution that can be downloaded by users for free.

For showing the proof of concept of WA+ in a complex basin, ET data of the Indus basin for 2007 was taken from the new ETLook algorithm (Bastiaanssen et al., 2012). ETLook is a two-layer surface energy balance model that adopts microwave-based soil moisture data to solve the partitioning of net radiation into latent heat flux, sensible heat flux and soil heat flux. ETLook computes evaporation $(E)$ and transpiration $(T)$ separately using leaf area index to partition total net radiation into canopy and soil components. ETLook also provides spatially distributed data for interception $(I)$ and a special subroutine for open water evaporation. Figures $2 \mathrm{c}$ and $1 \mathrm{~d}$ show the annual $E$ and $T$ values respectively, of the Indus basin. The total ET of the basin in 2007 was $501 \mathrm{~km}^{3}$, of which $T$ accounted for $229 \mathrm{~km}^{3}$ and $E$ and $I$ for $272 \mathrm{~km}^{3}$. The data were compared against field measurements of lysimeters, Bowen ratio flux towers, and water balance data in Pakistan (Bastiaanssen et al., 2012). The RMSE was $0.29 \mathrm{~mm} \mathrm{~d}^{-1}, R^{2}$ was 0.76 , and bias was $6.5 \%$.

The ETLook model also computes biomass production. The magnitude of Transpiration $(T)$ is related to the stomatal and canopy resistances. The stomatal resistance model for transpiration was used together with the Absorbed Photosynthetic Active Radiation (APAR) and Light Use Efficiency (LUE) to compute biomass production of vegetation, see Fig. 2b. More background information on biomass production is explained in Bastiaanssen and Ali (2003).

\subsection{Storage change}

$\mathrm{WA}+$ divides total water storage in a river basin into three groups, namely surface water storage, groundwater storage, and glacier reserves.

\subsubsection{Surface water storage}

Information on surface storage changes $\left(\Delta S_{\mathrm{sw}}\right)$ was acquired from dam operation agencies in Pakistan. Surface storage changes in the main reservoirs for this study were estimated by coupling water level fluctuation data with the size of the reservoir (see Table 1). A total surface storage depletion, 

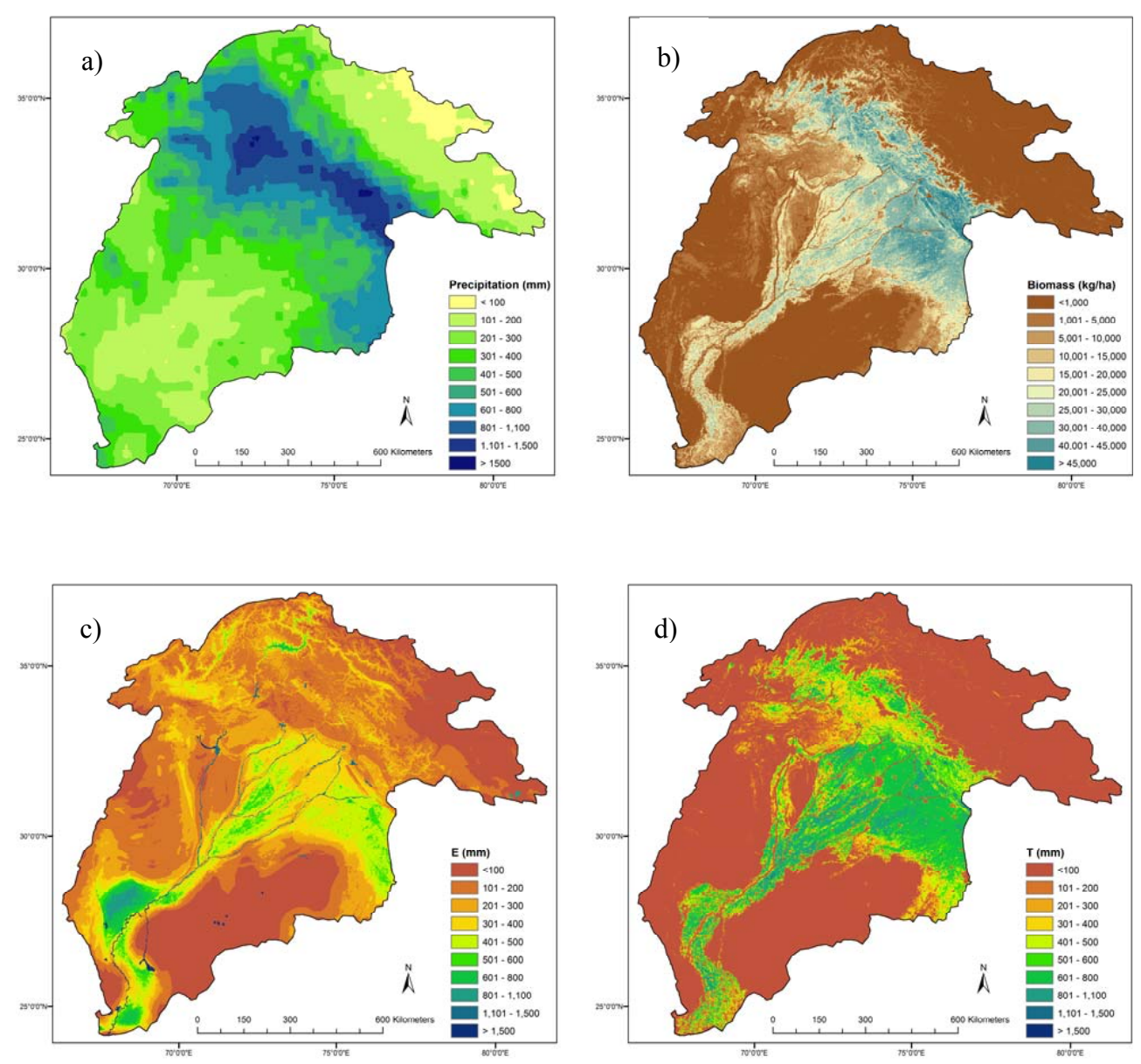

Fig. 2. (a) Precipitation (based on data from Cheema and Bastiaanssen, 2012) (b) biomass production (c) evaporation (d) transpiration (based on data from Bastiaanssen et al., 2012) in the Indus basin in 2007.

$\Delta S_{\mathrm{sw}}$, of $9.4 \mathrm{~km}^{3}$ was calculated for 2007 with most water released from Pong reservoir. While not a topic for this paper, it is interesting to note that remote sensing techniques are increasingly being utilized to estimate water level fluctuations from radar and laser altimetry. Water volume changes in reservoirs can be assessed by combining these level measurements with areal estimates (e.g. Birkett and Beckley, 2010; Zhang et al., 2011).

\subsubsection{Groundwater storage}

Information on groundwater storage at basin scale is limited. Changes in storage can be obtained from gravitational satellites such as the Gravity Recovery and Climate Experiment (GRACE) (e.g. Frappart et al., 2011; Henry et al., 2011). While this new source of data is appealing, the accuracy of GRACE data is to be improved to make it reliable for monitoring groundwater changes at the basin scale (e.g. Tang et al., 2010). Hydrological models simulate vertical and horizontal groundwater movements with discretized cells (e.g. Siebert et al., 2010; Wada et al., 2010) which then provides estimates of storage change. But these numerical models use gross assumptions about local groundwater withdrawals and are thus not very reliable. Data on withdrawals are normally obtained from tubewell density, electricity bills, farm interviews and changes in groundwater levels (e.g. Ahmad et al., 2005). This unfortunately does not provide a reliable and reproducible data set either. Despite heavy utilization of groundwater in the Indus, direct measurements on groundwater change remain limited. The WA+ offers the possibility to estimate total bulk groundwater storage change through mass conservation of the water balance. This is only feasible if the ET data can be estimated independently from the other terms of the water balance. These conditions were met for this demonstration study. The measured basin outflow was $21.3 \mathrm{~km}^{3}$, and this number was used to back-calculate total groundwater storage change by closing the water balance. It appears that groundwater storage depletion during 2007 was $29.8 \mathrm{~km}^{3}$. 
Table 1. Change in surface storage in the major reservoirs of Indus during 2007.

\begin{tabular}{lrrrr}
\hline Reservoir & $\begin{array}{r}\text { Reservoir } \\
\text { capacity }\left(\mathrm{km}^{3}\right)\end{array}$ & $\begin{array}{r}\text { Reservoir } \\
\text { area }\left(10^{9} \mathrm{~m}^{2}\right)\end{array}$ & $\begin{array}{r}\text { Water level } \\
\text { change }(\mathrm{m})\end{array}$ & $\begin{array}{r}\text { Change in surface } \\
\text { Storage }\left(\mathrm{km}^{3}\right)\end{array}$ \\
\hline Tarbela & 13.9 & 0.26 & -10.3 & -2.67 \\
Mangla & 7.3 & 0.25 & -10.6 & -2.65 \\
Chashma & 0.88 & 0.006 & +3.9 & +0.02 \\
Bhakra & 9.6 & 0.17 & -6.4 & -1.07 \\
Pong & 8.6 & 0.24 & -12.8 & -3.06 \\
\hline Total & 40.28 & 0.92 & & -9.4 \\
\hline
\end{tabular}

\subsubsection{Glacier and snow storages}

Glacier and snow melt are major contributors to river flow. The glacier area in the Indus basin is estimated at $22127 \mathrm{~km}^{2}$ (Immerzeel et al., 2010). Bolch et al. (2012) estimated the annual specific mass balance of Himalayan-Karakoram glacier to be around $-0.5 \mathrm{~m}$ per year during the last decade. Based on findings of Fowler and Archer (2006), the Karakoram glacier, with an area of $18000 \mathrm{~km}^{2}$, is believed to be stable. Hence, the snow storage change in the Indus basin is confined to a limited area only. The change in glacier storage over an area of $4127 \mathrm{~km}^{2}(22127-18000)$ will yield an annual stream flow of $2.1 \mathrm{~km}^{3}(4127 \times 0.5 \times 0.001=2.1)$ (W. W. Immerzeel, personal communication, 2012). Information on glacier storage change in a specific year is scant. We therefore used an average annual estimate as representative for 2007 in this study. This is a gross estimate which points to the desirability of future research.

\section{WA+ sheets for the Indus basin}

\subsection{Resource base sheet}

The WA+ resource base sheet for 2007 is presented in Fig. 3. The net inflow was $523 \mathrm{~km}^{3}$ of which $482 \mathrm{~km}^{3}$ originated from precipitation. The remaining $41 \mathrm{~km}^{3}$ was freshwater storage depletion. As described above, the major share of storage decline was ascribed to groundwater, $29.8 \mathrm{~km}^{3}$, followed by 9.4 and $2.1 \mathrm{~km}^{3}$ loss of storage from surface reservoirs and glaciers respectively.

Inter-basin transfer certainly occurs underground via the Quaternary upper tertiary deposits. The amounts are difficult to quantify however, and are assumed to be small in comparison to other water balance components. Due to the absence of documented estimates on groundwater outflow to the seaor intrusion - exchanges with the Indian Ocean were ignored as well. All inter-basin transfers were set at zero.

The net inflow was divided into landscape ET (green water: the direct ET from rainfall) and exploitable water (blue water: water in streams, lakes, reservoirs, snow cover, glaciers and aquifers). The landscape ET accounted

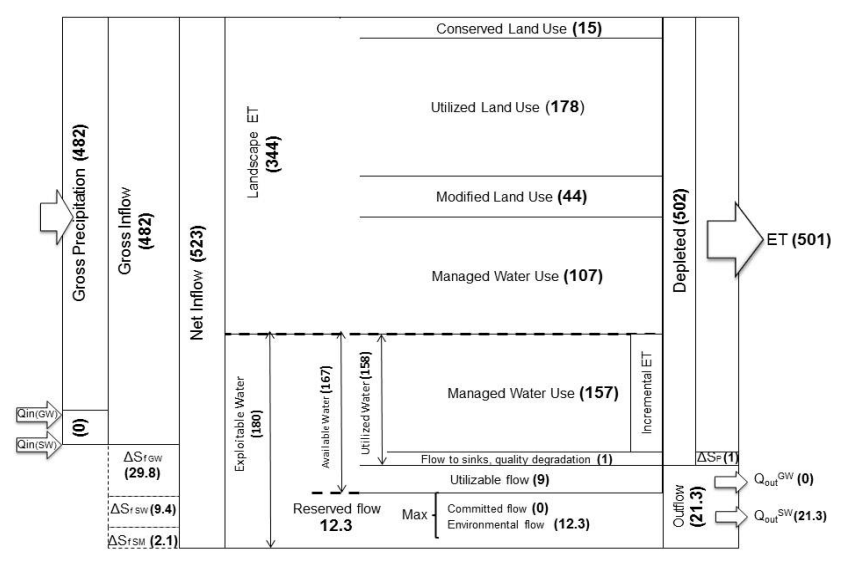

Fig. 3. WA+ resource base sheet for the Indus basin during 2007 . All components are in $\mathrm{km}^{3}$.

for $344 \mathrm{~km}^{3}$ ( $66 \%$ of the net inflow and $71 \%$ of total gross precipitation). This is a substantial water volume that can be managed only by modifying the land use and soil treatments. The exploitable water was $180 \mathrm{~km}^{3}$, at $34 \%$ of the net inflow.

The major water-depleting land use category was the group MWU. The total water depletion by MWU accounted for $264 \mathrm{~km}^{3}$, slightly over $50 \%$ of the net inflow. Of $264 \mathrm{~km}^{3}$, $107 \mathrm{~km}^{3}$ (or $41 \%$ ) was directly from rainfall over the irrigated areas, urban areas, and reservoirs; this is an integral part of landscape ET. The remaining incremental ET $\left(157 \mathrm{~km}^{3}\right)$ originated from utilized water flows.

The other components of the landscape ET include ET from CLU, ULU, and MLU. Within the landscape ET the group ULU used $178 \mathrm{~km}^{3}$ of water. These are the savanna, forests, deserts, and natural lakes which all provide ecosystem services. The group MLU (essentially rainfed crops) depleted $44 \mathrm{~km}^{3}$. The group CLU depleted only $15 \mathrm{~km}^{3}$. Table 2 shows the breakdown of ET by LULC classes within these groups.

Based on the Inter-provincial Water Apportion Accord 1991 , an amount of $12.3 \mathrm{~km}^{3}$ of flow should be set aside annually to meet the environmental flow requirements to curb seawater intrusion in the Indus Delta (Ram, 2010). This water volume, based on water rights formulation, is treated as 
Table 2. Water depletion by LULC class in the Indus basin in 2007.

\begin{tabular}{|c|c|c|c|c|}
\hline Land use class & $\begin{array}{l}\text { Land use } \\
\text { group }\end{array}$ & $\left(\mathrm{mcm}^{* *} \mathrm{yr}^{-1}\right)$ & $\begin{array}{r}T \\
\left(\mathrm{mcm} \mathrm{yr}^{-1}\right)\end{array}$ & $\begin{array}{r}\text { ET } \\
\left(\mathrm{mcm} \mathrm{yr}^{-1}\right)\end{array}$ \\
\hline Snow and ice permanent & CLU & 4376 & 157 & 4533 \\
\hline Conserved areas & CLU & 7025 & 3092 & 10117 \\
\hline Snow and ice temporary & ULU & 7199 & 927 & 8127 \\
\hline Bare soil & ULU & 7996 & 57 & 8053 \\
\hline Very sparse vegetation & ULU & 2979 & 94 & 3073 \\
\hline Pastures deciduous & ULU & 10713 & 368 & 11080 \\
\hline Pastures evergreen lowland & ULU & 6520 & 874 & 7394 \\
\hline Pastures deciduous alpine & ULU & 8125 & 234 & 8359 \\
\hline Savanna evergreen open & ULU & 6712 & 1984 & 8696 \\
\hline Savanna evergreen closed & ULU & 5757 & 7373 & 13130 \\
\hline Savanna deciduous & ULU & 23462 & 2829 & 26291 \\
\hline Forests evergreen needleleaf & ULU & 10627 & 18305 & 28932 \\
\hline Forests evergreen broadleaf & ULU & 1380 & 3682 & 5062 \\
\hline Forests deciduous alpine & ULU & 7,457 & 5550 & 13007 \\
\hline Forests/cropland alpine & ULU & 6497 & 15457 & 21955 \\
\hline Natural lakes, rivers & ULU & 15088 & 0 & 15088 \\
\hline Rainfed crops wheat/grams & MLU & 2641 & 857 & 3498 \\
\hline Rainfed crops mixed cotton, wheat rotation/fodder & MLU & 4,648 & 2541 & 7189 \\
\hline Rainfed crops general & MLU & 17194 & 3382 & 20576 \\
\hline Rainfed crops and woods & MLU & 8660 & 3702 & 12361 \\
\hline Irrigated mixed cotton, wheat rotation/orchards & MWU & 14973 & 31781 & 46754 \\
\hline Irrigated mixed cotton, wheat rotation/sugarcane & MWU & 17294 & 23889 & 41183 \\
\hline Irrigated rice, wheat rotation & MWU & 39161 & 67489 & 106649 \\
\hline Irrigated mixed rice, wheat rotation/cotton & MWU & 8679 & 12098 & 20776 \\
\hline Irrigated wheat, fodder rotation & MWU & 8,211 & 10851 & 19063 \\
\hline Irrigated rice, fodder rotation & MWU & 9366 & 8054 & 17420 \\
\hline Irrigated mixed rice, wheat rotation/sugarcane & MWU & 674 & 1105 & 1779 \\
\hline Urban and industrial settlements & MWU & 6731 & 2013 & 8744 \\
\hline Reservoirs & MWU & 1914 & 0 & 1914 \\
\hline
\end{tabular}

${ }^{*} E$ includes both evaporation and interception; ${ }^{* *} \mathrm{mcm}=$ million $\mathrm{m}^{3}$.

reserve flow in WA+. The difference between the exploitable water and the reserved flows $\left(167 \mathrm{~km}^{3}\right)$ is the available water of which $157 \mathrm{~km}^{3}$ was consumed by MWU as a result of water diversions and $1 \mathrm{~km}^{3}$ flowed to sinks (i.e. saline groundwater aquifers), rendering it unavailable for further use due to quality degradation. Given the non-existence of major flood events, non-utilizable flow which is mostly a consequence of major flood events, was assumed to be negligible in the accounting year. An amount of $21.3 \mathrm{~km}^{3}$ water flowed into the Indian Ocean. This figure was derived from discharge measurements (PBS, 2008).

Utilizable flow, the difference between available water and utilized water, was estimated at $8 \mathrm{~km}^{3}$ for 2007. Utilizable flow represents the amount that is available for further water resources development in an above-average rainfall year. To establish the amount reliably would need a multi-year assessment. The notable point is that, in the year assessed, the Indus basin has some surplus water leaving the basin, while it is losing its precious groundwater storage at a fast rate.

\subsection{Evapotranspiration sheet}

The WA+ evapotranspiration sheet (Fig. 4) divides the total ET into evaporation $(E)$, transpiration $(T)$ and interception $(I)$ for each LULC (Table 2). The evapotranspiration sheet also expresses the benefits, and the WA+ user can insert a judgment value to estimate to what extent water is consumed beneficially. Figure 4 shows the WA+ evapotranspiration sheet for the Indus for 2007. For this example all the transpiration was assumed to be $100 \%$ beneficial except for transpiration from floating vegetation in reservoirs, waste lands and weeds. All the interception was assumed non-beneficial, although interception has certain benefits for micro-meteorological conditions for crops. Except for evaporation from natural lakes, wetlands, rivers and industries (e.g. cooling towers, hydropower, etc.) all the evaporation was assumed $100 \%$ non-beneficial. These proportions of beneficial and non-beneficial $E$ and $T$ can be modified by users based on their judgment. 


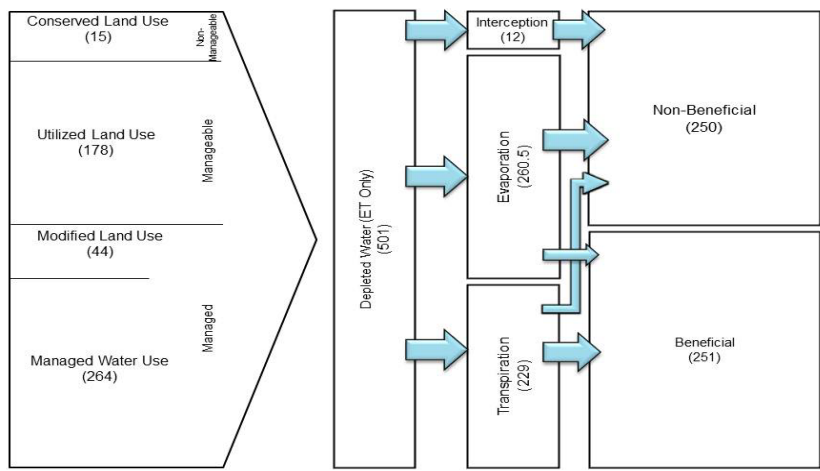

Fig. 4. WA + evapotranspiration sheet for the Indus basin based on 2007. All components are in $\mathrm{km}^{3}$.

In the accounting year, 261,229 , and $12 \mathrm{~km}^{3}$ were depleted by $E, T$ and $I$, respectively. This implies that bare soil $E$ is the main process through which water is depleted, being a surprisingly large number. As a consequence, beneficial water depletion was limited to only $50 \%$ of total water depletion. It comprises beneficial $E\left(22.5 \mathrm{~km}^{3}\right)$ plus $228.5 \mathrm{~km}^{3}$ beneficial $T$. Non-beneficial depletion accounted for $251 \mathrm{~km}^{3}$, with non-beneficial $E$ being the major contributor $\left(238 \mathrm{~km}^{3}\right)$. As demonstrated in Fig. $2 \mathrm{c}$, this occurred mainly in the downstream areas of the Sindh province. The total agricultural water depletion was $297 \mathrm{~km}^{3}$, of which $165 \mathrm{~km}^{3}(55 \%)$ occurred via $T$ and $132 \mathrm{~km}^{3}$ through $E$ and $I$. The average evaporation in irrigated areas, $380 \mathrm{~mm} \mathrm{yr}^{-1}$, is two times more than that in rainfed areas, $190 \mathrm{~mm} \mathrm{yr}^{-1}$. Given the fact that double cropping is the main practice in most of irrigated areas in the basin, the annual $E$ from rainfall is expected to be lower in irrigated areas compared to rainfed areas where the land remains fallow after the main cropping season is over. This indicates that more than half of the total evaporation in irrigated areas is associated with irrigation. This is an unfavorable situation that requires corrective action. For typical situations in irrigation systems, $T$ is $67 \%$ of the total ET (Ahmad et al., 2002). However, it is highly dependent on the pattern of rainfall.

\subsection{Productivity sheet}

Biomass production by LULC class is an indication of profits in terms of food, feed and fiber production (see Fig. 5). The total biomass production in the accounting year was 1015 million tons (Mt). Results show that MWU was the major contributor to biomass production $(596.7 \mathrm{Mt}$ and $21.4 \mathrm{tha}^{-1}$ ). MWU is followed by ULU that produced $356 \mathrm{Mt}$ of biomass in the accounting year, equal to $5.8 \mathrm{tha}^{-1}$. The remaining two classes, MLU and CLU, had minor shares in the total biomass production.

A total of $584 \mathrm{Mt}$ of $\mathrm{CO}_{2}$ was sequestered in the Indus basin through fresh biomass production. Further to the total biomass production, the annually sequestered carbon varies with land use class. For each land use class, the fraction of biomass that fixed carbon was specified. For instance, a large part of biomass of crops is removed from the field after harvest and does not contribute to carbon sequestration, except when crop residuals are ploughed and zero tillage is applied. For this study, we assumed the fraction to be $100 \%$ for land uses where vegetation is not removed (such as forests) and $15 \%$ for croplands where the crops are harvested and only a portion of biomass is left (mostly below ground biomass). These values can be defined by WA+ users based on their knowledge of the study area. Due to competition for space and light resources, each ecosystem has a certain maximum value of standing biomass. Part of the total standing biomass will be decayed by natural death and competition among species. This decay is not included in the production sheet.

The absorption of $390.8 \mathrm{Mt}$ of carbon annually shows the important role of that ULU in carbon absorption and thus as an ecosystem services provider. The ULU figure translates to $6.4 \mathrm{tha}^{-1}$, which is higher than the average $5.1 \mathrm{tha}^{-1}$ of $\mathrm{CO}_{2}$ in the basin. MWU is the second major land use group in terms of carbon sequestration. It fixed $160 \mathrm{Mt}$ of atmospheric $\mathrm{CO}_{2}$, equal to $5.7 \mathrm{tha}^{-1}$, and created soil organic matter. CLU contributed to $23 \mathrm{Mt}$ of $\mathrm{CO}_{2}$ sequestration followed by MLU with $10.3 \mathrm{Mt} \mathrm{CO}_{2}$. Note that this is gross sequestration and that net sequestration due to natural decay was not considered.

Land productivity was calculated for a hypothetical cereal reference crop with a harvest index of 0.35 . The average annual land productivity in MWU was $7.8 \mathrm{tha}^{-1} \mathrm{yr}^{-1}$. This figure in most areas represents the harvest of two seasons. For a single crop it would be 3.9 ton ha $^{-1}$, a value that is realistic for cereal crops in the Indus basin. Land productivity for rainfed agriculture was estimated at $0.94 \mathrm{tha}^{-1}$.

Water productivity (WP) is a fundamental indicator in performance assessment of river basins and it has immense food and water security implications (Molden, 2007). In the Indus basin, WP in terms of biomass production per hectare was close to $2 \mathrm{~kg} \mathrm{~m}^{-3}$. MWU had the highest biomass WP among all the land use groups $\left(2.3 \mathrm{~kg} \mathrm{~m}^{-3}\right)$. It is followed by $2.0,1.1$ and $1.1 \mathrm{~kg} \mathrm{~m}^{-3}$ for ULU, CLU, and MLU respectively. The average crop water productivity was calculated based on the estimated reference yields and annual ET. Results show crop WP in irrigated agriculture to be $0.77 \mathrm{~kg} \mathrm{~m}^{-3}$ and $0.35 \mathrm{~kg} \mathrm{ha}^{-1}$ for rainfed agriculture. This shows that WP in the basin is low compared to many other basins across the world (Cai et al., 2011). Zwart et al. (2010) reported $1.1 \mathrm{~kg} \mathrm{~m}^{-3}$ as the world average crop water productivity for wheat. Although certain pockets in the Indus basin have a WP value of $1.2 \mathrm{~kg} \mathrm{~m}^{-3}$ (Cai and Sharma, 2010), the average is $0.6 \mathrm{~kg} \mathrm{~m}^{-3}$, which is among the low performing basins in terms of productive use of water. One of the main contributing factors to the low WP is excessive $E$ from irrigated lands of which the majority is from irrigation. 


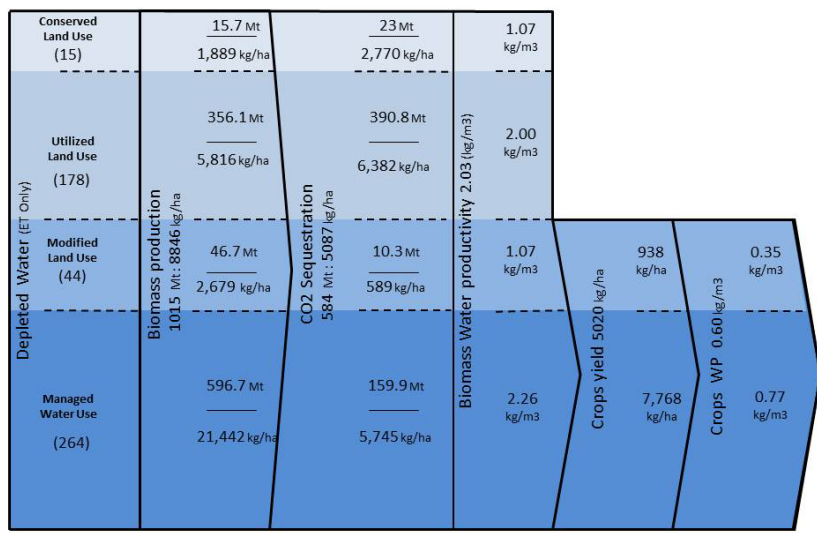

Fig. 5. WA + productivity sheet for the Indus basin pertaining to the year 2007. Water use figures are in $\mathrm{km}^{3}$.

\subsection{Withdrawal sheet}

The WA+ withdrawal sheet provides information on total withdrawal (surface water diversions and groundwater abstractions). Withdrawal data cannot be derived from satellite measurements. Other sources, such as secondary statistics and hydrological model outputs, need to be used if available. For the Indus basin, in addition to the remotely sensed data, FAO Aquastat database, canal water release information from the Line Agencies, and Soil and Water Assessment Tool (SWAT) model results were used to complete the WA+ withdrawal sheet.

The SWAT modeling results - after assimilating the remote sensing data - showed that an amount of $181 \mathrm{~km}^{3}$ of water was diverted for use in agriculture in 2007 (Cheema et al., 2013). Of this, $68 \mathrm{~km}^{3}$ originated from groundwater while surface water contributed $113 \mathrm{~km}^{3}$. Of the $181 \mathrm{~km}^{3}$ gross withdrawal for irrigation, $152 \mathrm{~km}^{3}$ was depleted by ET and the remaining non-consumed water $\left(30 \mathrm{~km}^{3}\right)$ was recovered in the system downstream of the point of application. Aquastat-estimated withdrawals for domestic and industrial uses as 12.2 and $1.8 \mathrm{~km}^{3}$ a year respectively; a combined withdrawal of $14 \mathrm{~km}^{3}$. The majority of the resource is groundwater, and we estimated that $10 \mathrm{~km}^{3}$ was abstracted by wells. Out of the $14 \mathrm{~km}^{3}$, an amount of $4.6 \mathrm{~km}^{3}$ was lost through ET, which leaves the majority to be nonconsumed $\left(9.4 \mathrm{~km}^{3}\right)$. The total ET from the LULC class "urban and industrial settlements" was $8.7 \mathrm{~km}^{3}$, which is larger than the $4.6 \mathrm{~km}^{3}$ (see Table 2), but part of the ET was attributed to rainfall. The incremental ET from reservoir operation was $1 \mathrm{~km}^{3}$. Figure 6 shows the WA+ withdrawal sheet for the Indus basin. Gross withdrawals in the accounting year was estimated at $196 \mathrm{~km}^{3}$, out of which $118 \mathrm{~km}^{3}$ $\left(113+4+1 \mathrm{~km}^{3}\right)$ was diverted from surface water system and $78 \mathrm{~km}^{3}\left(68+10 \mathrm{~km}^{3}\right)$ was extracted from aquifers.

After correction for non-recoverable flow to sinks, the recoverable flow will be $37.8 \mathrm{~km}^{3}$. The total return flow was

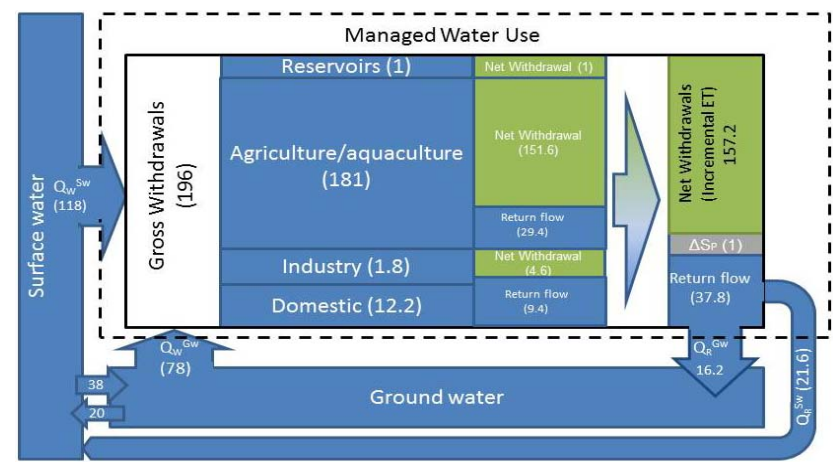

Fig. 6. WA+ withdrawal sheet for the Indus basin based on 2007 data. All components are in $\mathrm{km}^{3}$.

partitioned into surface water (SW) and groundwater (GW) recharge. Spatial data from the SWAT model was used to partition the return flows to $\mathrm{SW}\left(21.6 \mathrm{~km}^{3}\right)$ and $\mathrm{GW}\left(16.2 \mathrm{~km}^{3}\right)$. There is also a direct interaction between SW and GW within MWU. Seepage from irrigation canals was responsible for $38 \mathrm{~km}^{3}$ flowing from SW to GW. The flow from GW to SW was $20 \mathrm{~km}^{3}$ (Fig. 6). Combining all the numbers gives the mass balance of the bulk aquifer which indicated that groundwater storage depletion in MWU alone was $43.3 \mathrm{~km}^{3}$. The feeding of aquifers from the non-MWU classes (i.e. CLU, ULU, and MLU) was however not considered. Van Steenbergen and Gohar (2005) estimated this amount to be $14 \mathrm{~km}^{3}$, leaving the $\Delta S_{\mathrm{gw}}$ to be approximately $29.3 \mathrm{~km}^{3}$. A similar value of $29.8 \mathrm{~km}^{3}$ is presented in the resources base sheet.

\section{WA+ performance indicators}

The WA + offers a range of standard indicators (see Table 3). Every sheet comes with its own indicators that are derived from information in the sheets (Karimi et al., 2013). Table A1 in Appendix A summarizes the WA+ indicators definitions.

The WA+ resource base sheet indicators include a storage change fraction, an exploitable water fraction, an available water fraction, a basin closure fraction, and a reserved flow fraction. The exploitable water fraction (EWF) represents the portion of exploitable water in the net inflow. The storage change fraction (SCF) defines the portion of storage change in exploitable water. EWF is closely related to the natural run-off coefficient in a basin when no infrastructure is present, and when storage changes can be neglected. The Indus basin showed a EWF of 0.34 and its SCF was -0.23 . The available water fraction (AWF) indicates the proportion of the exploitable water that is actually available for withdrawals after corrections for reserved flows. The calculated AWF of the Indus basin was 0.93 , which indicates that the basin's water commitments are not a constraining factor for allocations. Indeed, most of the available water is utilized. 
Table 3. WA+ indicators for the Indus basin based on the situation in 2007.

\begin{tabular}{|c|c|c|c|}
\hline Indicators & Value & Unit & Remarks \\
\hline \multicolumn{4}{|l|}{ Resource base sheet } \\
\hline Exploitable water fraction & 0.34 & - & Plenty of renewable water resources \\
\hline Storage change fraction & -0.23 & - & Highly unsustainable practices \\
\hline Available water fraction & 0.93 & - & Low amount assigned to reserved flow \\
\hline Basin closure fraction & 0.95 & - & Almost closed to new development \\
\hline Reserved flow fraction & 0.58 & - & Downstream requirements are met \\
\hline \multicolumn{4}{|l|}{ Evapotranspiration sheet } \\
\hline$T$ fraction & 0.46 & - & Low canopy water depletion \\
\hline Beneficial fraction & 0.50 & - & Low benefits from water depletion \\
\hline Managed fraction & 0.61 & - & Many ET processes can be regulated \\
\hline Agri. ET fraction & 0.59 & - & Agriculture is a major water consumer \\
\hline Irri. ET fraction & 0.85 & - & Agriculture relies on irrigation water \\
\hline \multicolumn{4}{|l|}{ Productivity sheet } \\
\hline Land productivitycrops & 5020 & $\mathrm{~kg} \mathrm{ha}^{-1} \mathrm{yr}^{-1}$ & Very low crop yield \\
\hline Land productivity pastures & 177.4 & $\mathrm{~kg} \mathrm{ha}^{-1} \mathrm{yr}^{-1}$ & Extremely low grass yield \\
\hline Water productivity crops rainfed & 0.35 & $\mathrm{~kg} \mathrm{~m}^{-3}$ & Rainfed crops not efficient with water \\
\hline Water productivity crops irrigated & 0.77 & $\mathrm{~kg} \mathrm{~m}^{-3}$ & Irrigated crops not efficient with water \\
\hline Food Irri. Dependency & 0.90 & - & Food security relies on irrigation \\
\hline \multicolumn{4}{|l|}{ Withdrawals sheet } \\
\hline GW withdrawal fraction & 0.40 & - & Reliance on groundwater is significant \\
\hline CE (Classical irrigation efficiency) & 0.84 & - & Basin as a whole is an efficient system \\
\hline Recoverable fraction & 0.20 & - & Recycling situation is normal \\
\hline
\end{tabular}

Basin closure fraction (BCF) describes the extent to which available water is utilized in a basin. The Indus, for the single year investigated, had a BCF of 0.95 which shows utilized water is reaching its maximum in terms of volume. This leaves a limited window for further increases in withdrawals, especially during below-average rainfall years.

Reserved flow fraction (RFF) defines whether or not surface water outflow is meeting the required reserved flow. The RFF in the Indus basin was estimated at 0.58, which suggests that outflows from the basin were almost two times bigger than reserved flows. However, most of these outflows $\left(17.1 \mathrm{~km}^{3}\right)$ took place during the wet season (Kharif); outflow during the dry season (Rabi) was only $4.2 \mathrm{~km}^{3}$.

The WA+ evapotranspiration sheet has five indicators, namely a transpiration fraction, a beneficial fraction, a managed fraction, an agricultural ET fraction, and an irrigated ET fraction. The transpiration fraction gives an indication of which part of the ET is vaporized via plant leaves. For the Indus basin the ratio was 0.46 , meaning the majority of water depleted in 2007 in the basin was through soil and water evaporation and interception for canopies and other wet surfaces; something that is remarkable but unfavorable.

The managed fraction represents the portion of ET that is related to any kind of human intervention (MLU, MWU), and can be used to help save water (Seckler, 1996). MWU includes both rainfed and irrigated systems, as well as industrial and domestic uses. The managed fraction for the Indus basin in the accounting period was 0.61 , which implies that human activities in the basin dictate depletion of water to a large extent. The agricultural ET fraction in the basin was 0.59 , which shows that agricultural activities are intense water consumers. The reason is the extremely large extent of agriculturally related LULC area, covering almost $40 \%$ of the total area of the basin. The irrigated ET fraction for the basin was 0.85 , which indicates that $85 \%$ of agricultural ET was through irrigated systems.

The productivity sheet indicators are meant to reflect the basin's performance in productive use of land and water resources. Land productivity in cropped areas in the Indus basin was estimated at $5 \mathrm{tha}^{-1} \mathrm{yr}^{-1}$ (rainfed: $0.94 \mathrm{tha}^{-1} \mathrm{yr}^{-1}$; irrigated: $7.77 \mathrm{tha}^{-1} \mathrm{yr}^{-1}$ ). Land productivity of pastures is essential for grazing. Pasture productivity can also be used to value pastures in terms of economic benefit. Land productivity of pastures was about $0.18 \mathrm{tha}^{-1} \mathrm{yr}^{-1}$. Food irrigation dependency deals with the level to which a basin relies on irrigated agriculture for food production. The ratio was 0.9 for the Indus basin, indicating that food security 


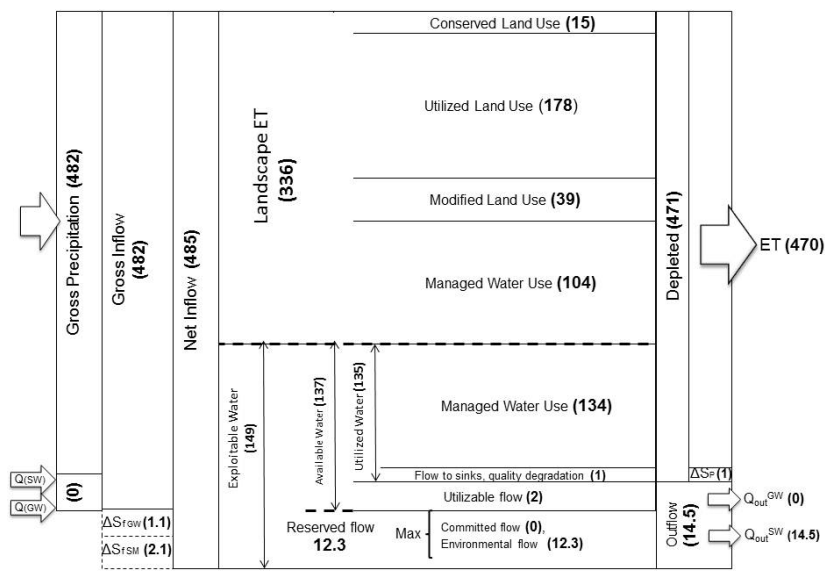

Fig. 7. Impact of scenario B on WA+ resource base sheet for the Indus. All components are in $\mathrm{km}^{3}$.

is highly dependent on continued irrigated agriculture. This is in fact a high number.

The results show the basin enjoys a relatively high classical irrigation efficiency of 0.84 at basin level (Seckler et al., 2003) despite its low classical irrigation efficiency of 0.35 to 0.40 at field scale (Qureshi, 2011). This implies that water is recycled about 4 times in the Indus basin. Hence, in general, the system is efficient in capturing and reusing nonconsumptive water use from farms and conveyance canals through the natural geographic setting. This WA+ performance indicator reveals that the irrigation efficiency for the basin is excellent, and will be difficult to improve. The recoverable fraction for the basin (0.2) indicates than $20 \%$ of the gross water withdrawals were recovered into the hydrological system and reused through surface and groundwater systems.

\section{Future scenario evaluation using WA+}

As mentioned earlier, this paper does not provide recommendations for the management of the Indus basin. The intention is merely to demonstrate the contribution of WA+ for appraising basin scale water management options. The 2007 WA+ results for the Indus demonstrate that there is limited scope for more water withdrawals in the basin and almost no opportunity to allocate more water for agriculture. In the remarks column of Table 3 a number of problems that need more attention are listed. The main problems can be summarized as follows:

- severe over-exploitation

- large reliance on groundwater resources

- high volumes of non-beneficial soil evaporation

- low crop yield in rainfed and irrigated land
- low crop water productivity in rainfed and irrigated land

- basin closure is almost reached

- insufficient storage capacity

- waterlogging in downstream areas.

For demonstration purposes, solutions for (i) zero overexploitation, and (ii) increasing land productivity has been worked out. Three different scenarios have been analyzed, aided by the WA+ framework (Table 4).

To meet the first goal of zero over-exploitation, storage depletion must be avoided. In 2007 the storage changes of groundwater and surface water were -29.8 and $-9.4 \mathrm{~km}^{3}$, respectively. Hence, for 2007 a real water saving of $39.3 \mathrm{~km}^{3}$ needed to be achieved. In nearly 8.8 million ha of irrigated lands in the basin soil evaporation $(E)$ accounted for more than $40 \%$ of ET. Limiting $E$ to $40 \%$ of the total ET would result in a net saving of $7.7 \mathrm{~km}^{3}$ of water. Water saving would increase significantly by $13.3 \mathrm{~km}^{3}$ if $E / \mathrm{ET}<0.36$ is introduced as a guideline in irrigated areas. There are several methods to reduce soil evaporation. Methods such as the use of drip systems and subsurface drip systems can significantly reduce soil evaporation losses of irrigated land (Wang et al., 2009). In rainfed systems, soil evaporation can be reduced by mechanical mulching (Prathapar and Qureshi, 1999) or by straw mulching (Zhang et al., 2003). E can also be reduced in shallow water table areas by means of installation of sub-surface drainage systems (Smedema, 2000).

It is not new to conclude that the crop water productivity in the Indus basin is low (Bastiaanssen et al., 2003; Cai and Sharma, 2010) and it is imperative to investigate options to improve yields if the increasing food demands are to be met. Crop yield is a function of biomass production and harvest index. The biomass production can be improved by better fertilization and the selection of good quality seeds. The uniformity, adequacy and reliability of irrigation systems contribute to the production of a healthy biomass (Murray-Rust et al., 1994). Uniform water distribution by means of drip systems and land leveling will ensure a low spatial variability of biomass. Adequate irrigation prevents moisture stress and reliable surface water supply will ensure that farmers invest more time and resources in their crop. With these measures a $5 \%$ increase in biomass production is plausible. A consequence of more biomass production is that $\mathrm{T}$ will increase at the same time. Steduto et al. (2009) established an empirical relationship between biomass production and $T$ which forms the basis of the AquaCrop model. Every increase of $1 \mathrm{~mm}$ in $T$ - normalized against reference $\mathrm{ET}_{0}$ - will increase biomass production by $13 \mathrm{~kg} \mathrm{ha}^{-1}$. So biomass production improvement will increase ET, unless $E$ is reduced concomitantly. Thus ET reduction can be achieved only if the reduction of $E$ exceeds the increase of $T$. The harvest index varies mainly with crop variety and the soil moisture situation during flowering and panicle stage. An adequate supply 
Table 4. Impact of alternative future scenario's on WA+ indicators aiming at zero-over-exploitation (storage change fraction) and increase food security (land productivity).

\begin{tabular}{|c|c|c|c|}
\hline Scenario & Action & $\begin{array}{l}\text { Real water saving } \\
\qquad\left(\mathrm{km}^{3} \mathrm{yr}^{-1}\right)\end{array}$ & WA+ indicators \\
\hline A Mixed actions & $\begin{array}{l}\text { Reduce } E \text { rainfed land by } 5 \% \mathrm{Re}- \\
\text { duce } E \text { irrigated land by } 15 \% \mathrm{Re}- \\
\text { duce irrigated area by } 0 \% \text { Biomass } \\
\text { production increase } 5 \% \text { Harvest in- } \\
\text { dex increase } 5 \% \\
\text { Reduce utilizable flow by } 50 \%\end{array}$ & 12.6 & $\begin{array}{l}\text { Storage change fr.: }-0.17 \\
\text { Reserved flow fr.: } 0.73 \\
T \text { fr.: } 0.48 \\
\text { Beneficial fr.: } 0.53 \\
\text { Land productivity irri: } 8,560 \\
\text { Land productivity rainfed: } 1,030 \\
\text { Water productivity irri: } 0.90 \\
\text { GW withdrawal fr.: } 0.41\end{array}$ \\
\hline B Reduce $E$ & $\begin{array}{l}\text { Reduce } E \text { rainfed land by } 15 \% \mathrm{Re}- \\
\text { duce } E \text { irrigated land by } 35 \% \mathrm{Re}- \\
\text { duce irrigated area by } 0 \% \text { Biomass } \\
\text { production increase } 5 \% \text { Harvest in- } \\
\text { dex increase } 10 \% \\
\text { Reduce utilizable flow by } 75 \%\end{array}$ & 37.8 & $\begin{array}{l}\text { Storage change fr.: }-0.02 \\
\text { Reserved flow fr.: } 0.85 \\
T \text { fr.: } 0.50 \\
\text { Beneficial fr.: } 0.55 \\
\text { Land productivity }_{\text {irri }}: 9300 \\
\text { Land productivity }_{\text {rainfed }}: 1130 \\
\text { Water productivity } \\
\text { GW wirr: } 1.09 \\
\text { GWdrawal fr.: } 0.32\end{array}$ \\
\hline C Modify area & $\begin{array}{l}\text { Reduce } E \text { rainfed land by } 5 \% \mathrm{Re}- \\
\text { duce } E \text { irrigated land by } 15 \% \mathrm{Re}- \\
\text { duce irrigated area by } 15 \% \text { Biomass } \\
\text { production increase } 5 \% \text { Harvest in- } \\
\text { dex increase } 10 \% \\
\text { Reduce non-utilizable flow by } 75 \%\end{array}$ & 39.4 & $\begin{array}{l}\text { Storage change fr.: }-0.01 \\
\text { Reserved flow fr.: } 0.85 \\
T \text { fr.: } 0.45 \\
\text { Beneficial fr.: } 0.50 \\
\text { Land productivity }_{\text {irri }}: 9300 \\
\text { Land productivity }_{\text {rainfed }}: 1,130 \\
\text { Water productivity } y_{\text {irri: }}: 0.93 \\
\text { GW withdrawal fr.: } 0.30\end{array}$ \\
\hline
\end{tabular}

during this critical period can increase the harvest index by 5 to $10 \%$ (Doorenbos and Pruitt, 1977).

Table 4 demonstrates the real water savings and the adjusted WA+ indicators under 3 scenarios, which are built around existing options to achieve water saving and better food security targets.

Scenario A involves some mixed interventions. Scenario $\mathrm{B}$ is based on reducing soil evaporation losses by mulching, drainage and micro-irrigation (drip and micro-sprinkler). Note that micro-irrigation will contribute to crop production and crop water productivity (Soman, 2012). Sub-surface irrigation is rapidly being adopted in India, and the same is feasible in Pakistan. Farmers will have a better future with improved livelihoods if scenario B is adopted by policy makers. Figure 7 shows the WA+ resource base sheet after implementing scenario B.

Scenario $\mathrm{C}$ is based on a land retirement plan. This is likely going to happen if other interventions are not implemented in a timely fashion.

$\mathrm{WA}+$ demonstrates that with these interventions, the future of the Indus basin will be more progressive. It is important to note that the above analyses are only based on results of water accounting in one year (2007) and are merely to demonstrate how the WA+ functions in scenario development and assessment. Therefore results must be treated with caution, and future research through multiple year analysis is required to validate the outcomes. Only options on reduced groundwater abstraction and increased food production have been investigated in depth. A more integrated approach is needed to formulate proper policy recommendations.

\section{Summary and conclusions}

Sustainable production in the Indus Basin is threatened by a host of issues, such as water scarcity, rapid population growth, groundwater over-exploitation, water logging, soil salinization and low productivity of land and water resources. A clear understanding of current water resources is the cornerstone for informed water management strategies for the future. However, data availability and a standard way of presenting data are two main obstacles in providing comprehensive, yet easy to comprehend, information on water management. The complexity of water is exacerbated in transboundary basins such at the river Indus.

In this study we used the Indus basin as an example to demonstrate how the WA + framework can be implemented 


\section{Appendix A}

Table A1. WA+ indictors definitions.

\begin{tabular}{ll}
\hline Indicators & Definition \\
\hline Exploitable water fraction & Exploitable water divided by the net inflow \\
Storage change fraction & Freshwater storage change divided by exploitable water \\
Available water fraction & Available water divided by exploitable water \\
Basin closure fraction & Utilized flow divided by available water \\
Reserved flow fraction & Reserved outflows divided by the total outflow \\
$T$ fraction & Total $T$ divided by the total ET \\
Beneficial fraction & Beneficial $E$ and $T$ divided by the total ET \\
Managed fraction & Managed ET divided by the total ET \\
Agri. ET fraction & Agricultural ET divided by the total ET \\
Irri. ET fraction & Irrigated agricultural ET divided by the agricultural ET \\
Land productivitycrops & Crop biomass times harvest index divided by cropped area \\
Land productivitypastures & Pastures biomass times harvest index divided by pasture area \\
Water productivity crops rainfed & Rainfed crops biomass times harvest index divided by rainfed crops ET \\
Water productivity crops irrigated & Irrigated crops biomass times harvest index divided by Irrigated crops ET \\
Food Irri. Dependency & Irrigated food production divided by total food production \\
GW withdrawal fraction & Groundwater withdrawals divided by total withdrawals \\
Classical irrigation efficiency & Incremental ET of agriculture divided by withdrawals for agriculture \\
Recoverable fraction & Return flow divided by total withdrawals \\
\hline
\end{tabular}

to provide much-needed explicit information on the water resources situation, depletion, and productivity in a systematic way by using minimum ground-measured data and accounting results that can be used to identify weaknesses, strengths, and opportunities.

The results suggest that the Indus basin is nearly a closed basin in which more than $95 \%$ of the available water is used. Almost all depleted water can be ascribed to ET. The managed water use group, chiefly dominated by irrigated agriculture, accounts for $52 \%$ of ET. It is followed by the utilized land use group (36\%), modified land use group (9\%) and conserved land use group (3\%). Half of the water depletion is through processes that produce very little or no benefits, i.e. non-beneficial depletion. The majority of these nonbeneficial depletion is through human-intended water use, particularly through irrigated agriculture in the form of excessive soil evaporation. Hence, large amounts of valuable groundwater resources are vaporized non-beneficially into the atmosphere.

On the supply side, precipitation falls short of meeting the water demand. This leads to significant reduction in storage, especially groundwater storage $\left(29.8 \mathrm{~km}^{3}\right.$ in 2007$)$. If the rapid decline in GW storage that occurred in 2007 is representative of other years, it may have major implications for the sustainability of the basin, considering the crucial role that GW plays in the basin's food security.

While agriculture accounts for $59 \%$ of total water depletion it has a considerably low productivity, especially in terms of water use. Therefore, to improve the situation and reach sustainability in the water-food nexus, it is wise to pro- vide attention to water and land productivity improvement. This will in turn result in increased production with reduced water consumption. The results suggest that of the main opportunities for reducing water depletion is through decreasing wasteful soil evaporation in agricultural areas, particularly in irrigated land. The results show - based on a single year analysis - that an amount of $37.8 \mathrm{~km}^{3}$ can be saved. If interventions are not timely implemented, retirement of irrigated land seems unavoidable.

Acknowledgements. Funds for this research were provided through the Capacity Building Program of the International Water Management Institute (IWMI) through the CGIAR Research Program on Water Land and Ecosystems. We are indebted to the review undertaken by Chris Perry and Mac Kirby. The authors are thankful to Vladimir Smakhtin and Robyn Johnston for their comments and contribution in improving this paper. The editors of HESS has provided valuable additional suggestions.

Edited by: G. Jewitt

\section{References}

Ahmad, M.-D., Bastiaanssen, W. G. M., and Feddes, R. A.: Sustainable use of groundwater for irrigation: a numerical analysis of the subsoil water fluxes, Irrig. Drain., 51, 227-241, 2002.

Ahmad, M.-D., Bastiaanssen, W. G. M., and Feddes, R. A.: A new technique to estimate net groundwater use across large irrigated areas by combining remote sensing and water balance approaches, Rechna Doab, Pakistan, Hydrogeol. J., 13, 653-664, 2005. 
Allen, R. G., Tasumi, M., and Trezza, R.: Satellite-Based Energy Balance for mapping evapotranspiration with internalized calibration (METRIC) - Model, J. Irrig. Drain. Eng., 133, 380-394, 2007

Anderson, M. C., Norman, J. M., Mecikalski, J. R., Otkin, J. A., and Kustas, W. P.: A climatological study of evapotranspiration and moisture stress across the continental United States based on thermal remote sensing: 1. Model formulation, J. Geophys. Res., 112, D10117, doi:10.1016/j.rse.2008.07.009, 2007.

Bartholomé, E. and Belward, A. S.: GLC2000: a new approach to global land cover mapping from Earth observation data, Int. J. Remote Sens., 26, 1959-1977, 2005.

Bastiaanssen, W. G. M. and Ali, S.: A new crop yield forecasting model based on satellite measurements applied across the Indus Basin, Pakistan, Agr. Ecosyst. Environ., 94, 321-340, 2003.

Bastiaanssen, W. G. M., Ahmad, M.-D., Tahir, Z., Kijne, J. W., Barker, R., and Molden, D.: Upscaling Water productivity in agriculture: limits and opportunities for improvement, edited by: Kijne, J. W., Barker, R., and Molden, D., CABI, Wallingford, 2003.

Bastiaanssen, W. G. M., Cheema, M. J. M., Immerzeel, W. W., Miltenburg, I., and Pelgrum, H.: The surface energy balance and actual evapotranspiration of the transboundary Indus Basin estimated from satellite measurements and the ETLook model, Water Resour. Res., 48, W11512, doi:10.1029/2011WR010482, 2012.

Bastiaanssen, W. G. M., Menenti, M., Feddes, R. A., and Holtslag, A. A. M.: A remote sensing surface energy balance algorithm for land (SEBAL). 1. Formulation, J. Hydrol., 212-213, 198-212, 1998.

Birkett, C. M. and Beckley, B.: Investigating the performance of the Jason-2/OSTM radar altimeter over lakes and reservoirs, Mar. Geod., 33, 204-238, 2010.

Bolch, T., Kulkarni, A., Kääb, A., Huggel, C., Paul, F., Cogley, J. G., Frey, H., Kargel, J. S., Fujita, K., Scheel, M., Bajracharya, S., and Stoffel, M.: The state and fate of Himalayan glaciers, Science, 336, 310-314, 2012.

Bontemps, S., Defourny, P., and Van Bogaert, E.: GLOBCOVER 2009 products ddescription and validation report, ESA and UCLouvin, 2010.

Cai, X., Molden, D., Mainuddin, M., Sharma, B., Ahmad, M.-D., and Karimi, P.: Producing more food with less water in a changing world: assessment of water productivity in 10 major river basins, Water Int., 36, 42-62, 2011.

Cai, X. and Sharma, B. R.: Integrating remote sensing, census and weather data for an assessment of rice yield, water consumption and water productivity in the Indo-Gangetic river basin, Agr. Water Manage., 97, 309-316, 2010.

Cheema, M. J. M.: Understanding water resources conditions in data scarce river basins using intelligent pixel information. Case: Transboundary Indus basin, PhD Thesis, TU Delft, 2012.

Cheema, M. J. M. and Bastiaanssen, W. G. M.: Land use and land cover classification in the irrigated Indus Basin using growth phenology information from satellite data to support water management analysis, Agr. Water Manage., 97, 1541-1552, 2010.

Cheema, M. J. M. and Bastiaanssen, W. G. M.: Local calibration of remotely sensed rainfall from the TRMM satellite for different periods and spatial scales in the Indus Basin, Int. J. Remote Sens., 33, 2603-2627, 2012.
Cheema, M. J. M., Immerzeel, W. W., and Bastiaanssen, W. G. M.: Spatial Quantification of Groundwater Abstraction in the Irrigated Indus Basin, Ground Water, doi:10.1111/gwat.12027, in press, 2013.

Doorenbos, J. and Pruitt, W. O.: Crop water requirements, Irrig. Drain. Paper No. 24, FAO, Rome, Italy, 1977.

Eastham, J., Kirby, M., Mainuddin, M., and Thomas, M.: Water-use accounts in CPWF basins: Simple water-use accounting of the Indus Basin. CPWF Working Paper: Basin Focal Project series, BFP07, Colombo, Sri Lanka, 28 pp., 2010.

Fowler, H. J. and Archer, D. R.: Conflicting signals of climatic change in the upper Indus basin, J. Climate, 19, 4276-4293, 2006.

Frappart, F., Papa, F., Güntner, A., Werth, S., Santos da Silva, J., Tomasella, J., Seyler, F., Prigent, C., Rossow, W. B., Calmant, S., and Bonnet, M.-P.: Satellite-based estimates of groundwater storage variations in large drainage basins with extensive floodplains, Remote Sens. Environ., 115, 1588-1594, 2011.

Friedl, M. A., Sulla-Menashe, D., Tan, B., Schneider, A., Ramankutty, N., Sibley, A., and Huang, X.: MODIS Collection 5 global land cover: Algorithm refinements and characterization of new datasets, Remote Sens. Environ., 114, 168-182, 2010.

Godfrey, J. M. and Chalmers, K.: Water accounting: International approaches to policy and decision-making, Edward Elgar Publishing, 2012.

GWSP: GlobalWater System Project DigitalWater Atlas data, available at: http://atlas.gwsp.org/ (last access: March 2013), 2008.

Habib, Z.: Resource conservation and civil society: water and food security in Pakistan, in: Water for food and rural development: Approaches and initiatives in South Asia, edited by: Molinga, P., 182-196, Sage Publication, New Delhi, India, 2000.

Henry, C. M., Allen, D. M., and Huang, J.: Groundwater storage variability and annual recharge using well-hydrograph and GRACE satellite data, Hydrogeol. J., 19, 741-755, 2011.

Hijmans, R. J., Cameron, S. E., Parra, J. L., Jones, P. G., and Jarvis, A.: Very high resolution interpolated climate surfaces for global land areas, Int. J. Climatol., 25, 1965-1978, 2005.

Immerzeel, W. W., Van Beek, L. P. H., and Bierkens, M. F. P.: Climate change will affect the Asian water towers, Science, 328, 1382-1385, 2010.

Joyce, R. J., Janowiak, J. E., Arkin, P. A., and Xie, P.: CMORPH?: A method that produces global precipitation estimates from passive microwave and infrared data at high spatial and temporal resolution, J. Hydrometeorol., 5, 487-503, 2004.

Kalma, J. D., McVicar, T. R., and McCabe, M. F.: Estimating land surface evaporation: A review of methods using remotely sensed surface temperature data, Surv. Geophys., 29, 421-469, 2008.

Karim, A. and Veizer, J.: Water balance of the Indus River Basin and moisture source in the Karakoram and western Himalayas: Implications from hydrogen and oxygen isotopes in river water, J. Geophys. Res., 107, 4362, doi:10.1029/2000JD000253, 2002.

Karimi, P., Molden, D., Bastiaanssen, W. G. M., and Cai, X.: Water accounting to assess use and productivity of water: evolution of a concept and new frontiers, in: Water accounting: International approaches to policy and decision-making, edited by: Godfrey, J. M. and Chalmers, K., 76-88, Edward Elgar Publishing, 2012.

Karimi, P., Bastiaanssen, W. G. M., and Molden, D.: Water Accounting Plus $(\mathrm{WA}+)$ - a water accounting procedure for complex river basins based on satellite measurements, Hydrol. 
Earth Syst. Sci., 17, 2459-2472, doi:10.5194/hess-17-24592013, 2013.

Laghari, A. N., Vanham, D., and Rauch, W.: The Indus basin in the framework of current and future water resources management, Hydrol. Earth Syst. Sci., 16, 1063-1083, doi:10.5194/hess-161063-2012, 2012.

Mitchell, T. D. and Jones, P. D.: An improved method of constructing a database of monthly climate observations and associated high-resolution grids, Int. J. Climatol., 25, 693-712, 2005.

Molden, D.: Water for food, water for life: A comprehensive assessment of water management in agriculture, Earthscan, 2007.

Murray-Rust, D. H., Gulati, O. T., Sakthivadivel, R., Prajapati, V. B., and Shukla, P. L.: Improving irrigation performance through the use of management information systems: The case of Mahi Kadana, Gujarat, India, International Water Management Institute, Colombo, Sri Lanka, 1994.

Norman, J. M., Kustas, W. P., Prueger, J. H., and Diak, G. R.: Surface flux estimation using radiometric temperature: A dual-temperature-difference method to minimize measurement errors, Water Resour. Res., 36, 2263-2274, doi:10.1029/2000WR900033, 2000.

PBS: Rainfall at Selected Stations, available at: http: //www.pbs.gov.pk/sites/default/files/agriculture_statistics/ rainfall_at_Selected_Stations.pdf (last access: 12 September 2012), 2008.

Prathapar, S. A. and Qureshi, A. S.: Mechanically reclaiming abandoned saline soils: A numerical evaluation, International Water Management Institute, Colombo, Sri Lanka, 1999.

Qureshi, A. S.: Water management in the Indus basin in Pakistan: challenges and opportunities, Mt. Res. Dev., 31, 252-260, 2011.

Ram, N.: An analysis of rural poverty trends in Sindh province of Pakistan, Aust. J. Basic Appl. Sci., 4, 1403-1409, 2010.

Seckler, D.: The new era of water resources management: From "dry" to "wet" water savings, International Water Management Institute, Colombo, Sri Lanka, 1996.

Seckler, D., Molden, D., and Sakthivadivel, R.: The concept of efficiency in water resources management and policy, in water Productivity in agriculture: Limits and opportunities for improvement, edited by: Kijne, J. W., Barker, R., and Molden, D., Comprehensive assessment of water management in Agriculture, CABI Publishing in association with International Water Management Institute, UK, 37-52, 2003.

Siebert, S., Burke, J., Faures, J. M., Frenken, K., Hoogeveen, J., Döll, P., and Portmann, F. T.: Groundwater use for irrigation - a global inventory, Hydrol. Earth Syst. Sci., 14, 1863-1880, doi:10.5194/hess-14-1863-2010, 2010.

Smedema, L.: Irrigation-induced river salinization: Five major irrigated basins in the arid zone, International Water Management Institute, Colombo, Sri Lanka, 2000.

Soman, P.: Drip irrigation and fertigation technology for rice cultivation, in Asian Irrigation Forum 2012, Manila, Philippines, 2012 .
Sorooshian, S., Hsu, K.-L., Gao, X., Gupta, H. V., Imam, B., and Braithwaite, D.: Evaluation of PERSIANN system satellitebased estimates of tropical rainfall, B. Am. Meteorol. Soc., 81, 2035-2046, 2000.

Steduto, P., Hsiao, T. C., Raes, D., and Fereres, E.: AquaCrop - The FAO crop model to simulate yield response to water: I. Concepts and underlying principles, Agron. J., 101, 426-437, 2009.

Su, Z.: The Surface Energy Balance System (SEBS) for estimation of turbulent heat fluxes, Hydrol. Earth Syst. Sci., 6, 85-100, doi:10.5194/hess-6-85-2002, 2002.

Tang, Q., Gao, H., Yeh, P., Oki, T., Su, F., and Lettenmaier, D. P.: Dynamics of terrestrial water storage change from satellite and surface observations and modeling, J. Hydrometeorol., 11, 156170, 2010.

Thenkabail, P. S., Schull, M., and Turral, H.: Ganges and Indus river basin land use/land cover (LULC) and irrigated area mapping using continuous streams of MODIS data, Remote Sen. Environ., 95, 317-341, 2005.

UN: System of Environmental Economic Accounting for Water, Geneva, 2007.

Van Steenbergen, F. and Gohar, S.: Ground water development and Management, World Bank, Background paper 12, 2005.

Verstraeten, W. W., Veroustraete, F., and Feyen, J.: Estimating evapotranspiration of European forests from NOAA-imagery at satellite overpass time: Towards an operational processing chain for integrated optical and thermal sensor data products, Remote Sens. Environ., 96, 256-276, 2005.

Wada, Y., Van Beek, L. P. H., Van Kempen, C. M., Reckman, J. W. T. M., Vasak, S., and Bierkens, M. F. P.: Global depletion of groundwater resources, Geophys. Res. Lett., 37, L20402, doi:10.1029/2010GL044571, 2010.

Wang, Z., Liu, Z., Zhang, Z., and Liu, X.: Subsurface drip irrigation scheduling for cucumber (Cucumis sativus L.) grown in solar greenhouse based on $20 \mathrm{~cm}$ standard pan evaporation in Northeast China, Sci. Hortic., 123, 51-57, 2009.

Wu, B., Yan, N., Xiong, J., Bastiaanssen, W. G. M., Zhu, W., and Stein, A.: Validation of ETWatch using field measurements at diverse landscapes: A case study in Hai Basin of China, J. Hydrol., 436-437, 67-80, 2012.

Zhang, G., Xie, H., Duan, S., Tian, M., and Yi, D.: Water level variation of Lake Qinghai from satellite and in situ measurements under climate change, J. Appl. Remote Sens., 5, 053532-1-053532$15,2011$.

Zhang, X., Pei, D., and Hu, C.: Conserving groundwater for irrigation in the North China Plain, Irrig. Sci., 21, 159-166, 2003.

Zwart, S. J., Bastiaanssen, W. G. M., De Fraiture, C. and Molden, D. J.: WATPRO: A remote sensing based model for mapping water productivity of wheat, Agr. Water Manage., 97, 1628-1636, doi:10.1016/j.agwat.2010.05.017, 2010. 